\title{
Proposta de classificação da função velofaríngea na avaliação perceptivo-auditiva da fala $* * * * * *$
}

\author{
Proposal for velopharyngeal function rating in a speech \\ perceptual assessment
}

\author{
Inge Elly Kiemle Trindade* (ingetrin@usp.br) \\ Katia Flores Genaro** \\ Renata Paciello Yamashita*** \\ Haline Coracine Miguel**** \\ Ana Paula Fukushiro*****
}

\author{
*Biomédica. Professora Titular em \\ Fisiologia do Departamento de \\ Ciências Biológicas da Faculdade de \\ Odontologia de Bauru da Universidade \\ de São Paulo (FOB-USP). \\ **Fonoaudióloga. Professora \\ Associada do Departamento de \\ Fonoaudiologia da FOB-USP. \\ ***Fonoaudióloga do Hospital de \\ Reabilitação de Anomalias \\ Craniofaciais da Universidade de São \\ Paulo (HRAC-USP). Doutora em \\ Distúrbios da Comunicação Humana \\ (DCH) pelo HRAC-USP. \\ *****Fonoaudióloga do HRAC-USP. \\ Mestre em DCH pelo HRAC-USP. \\ *****Fonoaudióloga do HRAC-USP \\ Doutoranda em CDH pelo HRAC-USP. \\ ******Trabalho Realizado no \\ Laboratório de Fisiologia do HRAC- \\ USP, Bauru, SP. \\ Artigo de Atualização \\ Artigo Submetido a Avaliação por Pares \\ Conflito de Interesse: não
}

\begin{abstract}
Background: the perceptual assessment of velopharyngeal function during speech presents some limitations due to its subjectivity. Aim: to propose a method for velopharyngeal function rating based on hypernasality, nasal air emission and compensatory articulation deficits scores. Conclusion: the proposed method shows several advantages in terms of clinical and research documentation and for an adequate follow-up of therapeutic and surgical outcomes.
\end{abstract}

Key Words: Velopharyngeal Insufficiency; Hypernasality; Nasal Emission; Craniofacial Articulation Disorders.

\section{Resumo}

Tema: a avaliação perceptivo-auditiva da função velofaríngea apresenta limitações em função de sua subjetividade. Objetivo: propor um método de classificação baseado nos escores atribuídos à hipernasalidade, emissão de ar nasal e distúrbios articulatórios compensatórios. Conclusão: o uso do método traz inúmeras vantagens em termos de documentação clínica e de pesquisa e para acompanhamento de resultados terapêutico-cirúrgicos.

Palavras-Chave: Insuficiência Velofaríngea; Hipernasalidade; Emissão Nasal; Transtornos da Articulação Craniofacial.

Recebido em 28.10.2003.

Revisado em 1.03.2004; 14.06.2004; 2.12.2004; 7.02.2005; 10.06.2005.

Aceito para Publicação em 24.06.2005. 


\section{Introduction}

Normal velopharyngeal function is achieved by the synchronized movement of structures of the velopharyngeal mechanism - soft palate, lateral and posterior pharyngeal walls - which play a fundamental role in the production of speech, since it is responsible for the distribution of the expiratory airflow and acoustic vibrations to the oral cavity, during the production of oral sounds, and to the nasal cavity, during the production of nasal sounds (Camargo et al., 2001; Kummer, 2001). The inadequacy of the velopharyngeal mechanism may affect the speech in different manners. The term velopharyngeal dysfunction (VPD) is employed to indicate any alteration in the velopharyngeal mechanism resulting from the lack of tissue for achievement of proper velopharyngeal closure (velopharyngeal insufficiency), lack of neuromuscular competence in the movement of velopharyngeal structures (velopharyngeal incompetence), or even as a consequence of velopharyngeal mislearningmaladaptative velopharyngeal function, not related to physical or neuromuscular problems (Johns et al., 2003). The most common speech symptoms of VPD are hypernasality, nasal air emission (audible or not) and compensatory articulation (Trindade and Trindade Junior, 1996; Zuiani et al., 1998; Kummer, 2001; Yamashita et al., 2002; Johns et al., 2003).

Hypernasality is one of the most remarkable clinical manifestations of VPD and may be described as a change indeviant vocal quality resulting from an abnormal open communication between nasal and oral cavities. It corresponds to an excessive nasal resonance following of normally non-nasal sounds. From a physiological point of view, hypernasality results from the inability inadequate closure of the velopharyngeal mechanism to keep closed enough to avoidwhich yields to nasal resonance of sounds that usually are orally articulated resonated (Kummer, 2001; Peterson-Falzone et al., 2001).

Nasal air emission is also a characteristic of VPD. It corresponds to the improper emission of airflow through the nose during production of pressure consonants. The nasal emission of air is noticed during the production of plosive, fricative and affricate pressure consonants and may vary from non-audible emissions to a more severe form of audible emission, called nasal turbulence (Kummer, 2001; Johns et al., 2003).

The lack of velopharyngeal closure further leads to the development of compensatory articulations, which may be considered as strategies to compensate for the inability to create pressure in the oral cavity. According to Trindade and Trindade Junior (1996), from an aerodynamic point of view, the primary effect of the failure in the articulation performance of the velopharyngeal structures is the development of a weak intraoral air pressure during production of plosive, fricative and affricate consonants, associated towith nasal air emission. Thus, individuals with VPD frequently replace orally articulated sounds by sounds articulated at points behind the area of impairment, in an often unconscious attempt to approximate the acoustic output to a normal sound as much as possible. The most frequent compensatory articulations secondary to VPD are: glottal stop, pharyngeal fricative, pharyngeal stop, velar fricative, mid-dorsum palatal stop and posterior nasal fricative (Kummer, 2001; Peterson-Falzone et al., 2001).

Perceptual assessment of speech is the main indicator of the clinical significance of VPD related symptoms; as such, it is an essential part in the diagnosis of VPD, along with physical examination and clinical history (Trindade and Trindade Junior, 1996; Kummer et al., 2003). By perceptually evaluating of resonance and the presence or not absence of nasal air emission and compensatory articulation during speech, it is possible to rate the velopharyngeal function. However, despite its wellrecognized importance, the perceptual assessment presents some limitations due to its subjectivity. , including the need of multiple examiners for validation of measurements and the difficulty to achieve uniformity between examiners, even when trained (Trindade and Trindade Junior, 1996). Thus, in order to minimize the subjectivity of VPD perceptual assessment and increase its reproducibility, i.e. improve the agreement of judgments for a same examiner at different moments or between different examiners, a new method for velopharyngeal function rating, based on scores, is proposed.Thus, a structured protocol of clinical judgement of velopharyngeal function based on scores, is proposed.

Based on the protocol of speech perceptual assessment evaluation used at the Laboratory of Physiology (HRAC-USP), established according to the protocol of Dalston (1983) adapted to the Portuguese language (Trindade and Trindade Junior, 1996), velopharyngeal function is scored considering according to the following aspects of 
speech: hypernasality, nasal air emission and compensatory articulation.

Resonance is assessed during a sample of spontaneous speech and also during repetition of words and phrases. As to hypernasality, resonance is scored by using a 6-point scale, in which $1=$ absence of hypernasality (normal oro-nasal resonance), $2=$ mild hypernasality, $3=$ mild to moderate hypernasality, $4=$ moderate hypernasality, $5=$ moderate to severe hypernasality, and $6=$ severe hypernasality. Scores equal or higher than 2 are considered clinically significant.

TABLE 1. Classification of velopharyngeal function according to hypernasality, nasal air emission and compensatory articulation scores.

\begin{tabular}{cc|cc}
\hline \multicolumn{4}{c}{ Características da Fala } \\
Hipernasalidade* & Emissão Nasal* & $\begin{array}{c}\text { Função } \\
\text { Articulações } \\
\text { Compensatórias \# }\end{array}$ & Velofaríngea \\
1 & 1 & 1 & 1 = adequada \\
1 & 2 & 1 & \\
1 & 3 & $1-2$ & $2=$ marginal \\
2 & $1-3$ & $1-2$ & $3=$ inadequada \\
3 & $1-3$ & $1-2$ & \\
2 & $4-6$ & $1-2$ & $1-2$ \\
3 & $4-6$ & $1-2$ & \\
$4-6$ & $2-6$ & &
\end{tabular}

* 1 ausente; 2 leve; 3 leve para moderada; 4 moderada; 5 moderada para grave; 6 grave.

\# 1 ausente; 2 presente.

TABLE 2. Velopharyngeal function (VPF) scores in three cases followed at the Laboratory of Physiology, assigned on the basis of scores of hypernasality $(\mathrm{H})$, nasal emission (NE) and presence of compensatory articulation (CA) during speech. PRE represents the preoperative condition, and POST the postoperative condition.

\begin{tabular}{|c|c|c|c|c|c|c|c|c|}
\hline \multirow{2}{*}{ Condição } & \multicolumn{2}{|c|}{$\mathrm{H}$} & \multicolumn{2}{|c|}{ EN } & \multicolumn{2}{|c|}{$\mathrm{AC}$} & \multicolumn{2}{|c|}{ FVF } \\
\hline & Pré & Pós & Pré & Pós & Pré & Pós & Pré & Pós \\
\hline $\begin{array}{c}\text { exemplo } 1 \\
\text { Palatoplastia }\end{array}$ & 2 & 1 & 2 & 1 & 1 & 1 & 2 & 1 \\
\hline $\begin{array}{l}\text { exemplo } 2 \\
\text { Faringoplastia }\end{array}$ & 4 & 1 & 4 & 1 & 2 & 1 & 3 & 1 \\
\hline $\begin{array}{c}\text { exemplo } 3 \\
\text { Ortognática }\end{array}$ & 1 & 3 & 1 & 4 & 1 & 1 & 1 & 3 \\
\hline
\end{tabular}

Nasal air emission is scored according to the amount of nasal air emission, as evidenced by mirror fogging, during blowing, prolonged emission of phonemes /i/,/u/, /f/, /s/ and /ò/ and of words and phrases with plosive and fricative phonemes, on a 6-point scale, in which $1=$ absence of nasal air emission, $2=$ mild nasal air emission, $3=$ mild to moderate nasal air emission, $4=$ moderate nasal air emission, $5=$ moderate to severe nasal air emission, and $6=$ severe nasal air emission. Scores equal or higher than 3 are considered clinically significant.

Compensatory articulation is scored on a 2point scale, in which $1=$ absent, or $2=$ present.

Based Depending on the combination of scores observed forof hypernasality, nasal air emission and presence or absence of compensatory articulation, velopharyngeal function is then scored in a 3 -point scale, in which $1=$ adequate velopharyngeal function, $2=$ borderline velopharyngeal function, and 3 = inadequate velopharyngeal function, as demonstrated shown in Table 1. According to the proposed criteria, a subject whose speech is scored as $1 / 1 / 1$, meaning that there is no hypernasality, no nasal emission and no compensatory articulation, is diagnosed as having an adequate velopharyngeal function, scored as 1 . Using the same rationale, a subject with a score of $6 / 6 / 2$, meaning severe hypernasality, severe nasal emission and presence of compensatory articulation is diagnosed as having an inadequate velopharyngeal function, scored as 3 .

For purposes of illustration, Ttable 2 illustrates shows three situations commonly observed at the cleft clinic, which demonstrate the importance of this method for velopharyngeal function scoring, especially for the follow-up of surgical outcomes. The first example presents data of a patient with submucous cleft palate in need of primary palatoplasty. In the pre-surgical speech perceptual assessment, hypernasality was scored as mild (2), nasal air emission as mild (2), and there were no compensatory articulations (1). Based on the pattern $2 / 2 / 1$, velopharyngeal function was scored as 2 (borderline) (2). The patient was submitted to palatoplasty, and post-surgical assessment (5 months) revealed elimination of hypernasality (1) and nasal air emission (1). Thus, after surgery, the pattern 1/1/1 was observed, which corresponds to adequate velopharyngeal function (1). Analysis of the scores assigned to this patient before and after surgery clearly demonstrate the effectiveness of palatoplasty for this patient, who initially presented borderline velopharyngeal function. The second 
example refers to a patient with operated cleft lip and palate, with VPD and in need of pharyngeal flap surgery. In pre-surgical speech perceptual assessment, the patient showed moderate hypernasality (4), moderate nasal air emission (4) and presence of compensatory articulation (2). Based on the pattern $4 / 4 / 2$, the patient was classified as having inadequate velopharyngeal function (3) in the pre-surgical period. The patient was then submitted to superiorly based pharyngeal flap surgery. The post-surgical assessment ( 1 year and 6 months) revealed normal oro-nasal resonance (1), absence of nasal air emission (1) and absence of compensatory articulations (1). In other words, after surgery, the observed pattern was $1 / 1 / 1$, and velopharyngeal function was classified as adequate (1). Data clearly show the resolution of velopharyngeal inadequacy produced by the pharyngeal flap (from 3 to 1). Finally, the third example presents data of a patient with operated cleft lip and palate with maxillary deficiency and in need of orthognathic surgery. In the pre-surgical speech perceptual assessment, the patient presented normal oronasal resonance (1); absence of nasal air emission (1) and absence of compensatory articulation (1). Based on the pattern 1/1/1, the pre-surgical velopharyngeal function was scored as 1 (adequate). The patient was then submitted to orthognathic surgery involving maxillary advancement in two segments with grafting, bilateral turbinectomy and septoplasty. Postsurgical assessment (5 months) demonstrated mild to moderate hypernasality (3), moderate nasal air emission (4) and absence of compensatory articulations (1). According to the pattern 3/4/1, velopharyngeal function at the post-surgical period was scored as 3 (inadequate) (3). Analysis of the scores clearly demonstrates the deterioration of velopharyngeal function caused by orthognathic surgery with maxillary advancement, from 1 to 3 .

\section{Conclusion}

The classification of velopharyngeal function by scores as proposed in the present study has been routinely used in the clinical practice of the Laboratory of Physiology at HRAC-USP, i. ncorporated in a speech report for each patient. It In face of the usual descriptive nature of perceptual evaluations, the use of a more structured protocol has proved shown to be a useful tool in the diagnosis of velopharyngeal dysfunction and for the a method that significantly contributes for a better agreement among judges, facilitates documentation of findings, particularly in the and allows the follow-up of surgical and therapeutic outcomes. An ongoing study at our laboratory aims at showing that the proposed protocol also improves intra- and interjudge agreement. The authors ' experience to date is that it is a beneficial addition to the cleft clinic, besides the evident applications in clinical research.

\section{References}

CAMARGO, L. O. S.; RODRIGUES, C. M.; AVELAR, J. A. Oclusão velofaríngea em indivíduos submetidos à nasoendoscopia na clínica de educação para saúde (CEPS). Salusvita, Bauru, v. 20, n. 1, p. 35-48, 2001.

DALSTON, R. M. Computer-generated reports of speech and language evaluations. Cleft Palate J., Baltimore, v. 20, n. 3, p. 227-237, July 1983.

JOHNS, D. F.; ROHRICH, R. J.; AWADA, M. Velopharyngeal incompetence: a guide for clinical evaluation. Plast. Reconst. Surg., Hagerstown, v. 112, n. 7, p. 1890-1897, dec. 2003.

KUMMER, A. W. Velopharyngeal dysfunction (VPD) and resonance disorders. In: KUMMER, A. W. Cleft palate \& craniofacial anomalies: effects on speech and resonance. San Diego: Singular, 2001. cap. 7, p. 145-176.

KUMMER, A. W.; BRIGGS, M.; LEE, L. The relationship between the characteristics of speech and velopharyngeal gap size. Cleft Palate-Craniofac. J., Chapel Hill, v. 40, n. 6, p. 590-596, nov. 2003.

PETERSON-FALZONE, S. J.; HARDIN-JONES, M. A.; KARNELL, M. P. Communication disorders associated with cleft palate. In: PETERSON-FALZONE, S. J.; HARDINJONES, M. A.; KARNELL, M. P. Cleft palate speech. Saint Louis: Mosby; 2001. cap. 7, p. 162-198.

TRINDADE, I. E. K.; TRINDADE JUNIOR, A. S. Avaliação funcional da inadequação velofaríngea. In: CARREIRÃO, S.; LESSA, S.; ZANINI, A. S. (Ed.). Tratamento das fissuras labiopalatinas. 2. ed. Rio de Janeiro: Revinter; 1996. cap. 26, p. 223-235.

YAMASHITA R. P.; CALAIS, L. L.; MIGUEL, H. C.; TRINDADE, I. E. K. Avaliação da resistência laríngea em indivíduos portadores de insuficiência velofaríngea com distúrbio articulatório compensatório. Acta Awho, São Paulo, v. 21, n. 2, abr.-jun. 2002. Disponível em: <http:// www.actaawho.com.br/default.asp?edi_id=5>. Acesso em 26 nov. 2004

ZUIANI, T. B. B.; TRINDADE, I. E. K.; YAMASHITA, R. P.; TRINDADE JUNIOR, A. S. The pharyngeal flap surgery in patients with velopharyngeal insufficiency: perceptual and nasometric speech assessment. Braz. J. Dysmorphol. Speech Dis., Bauru, v. 2, n. 1, p. 31-42, July, 1998.

Endereço para correspondência:

Inge Elly Kiemle Trindade

R. Sílvio Marchione 3-20 - Vila Universitária - Bauru - SP - CEP: 17012-900. 